\title{
IMPLEMENTASI EKSEKUSI PUTUSAN BANI DALAM PENYELESEAIAN SENGKETA PERDATA
}

\author{
Heru Suyanto, Heru Sugiyono, Ilvana Oktalia \\ Fakultas Hukum Universitas Pembangunan Nasional Veteran Jakarta \\ Jalan RS. Fatmawati No.1, Jakarta Selatan, Indonesia \\ Email: herusuyanto@upnvj.ac.id,herusugiyono@upnvj.ac.id, \\ ilvanaoktalia@gmail.com
}

\begin{abstract}
Abstrak
Arbitrase merupakan salah satu bentuk cara penyelesaian sengketa perdata yang timbul dari pelaksanaan suatu perjanjian diantara para pihak. Sengketa pardata dapat diselesaikan melalui Badan Arbitrase Nasional Indonesia (BANI) jika dalam perjanjian yang dibaut oleh para pihak tercantum klausula pilihan jika terjadi sengketa akan diselesaikan melalui BANI. Putusan BANI harus dilaksanakan dengan itikad baik oleh para pihak yang terikat dalam perjanjian, dan jika putusan tidak dilaksanakan secara sukarela maka akan dilakukan eksekusi oleh Pengadilan Negeri. Dalam penelitian ini penulis menggunakan metode penelitian yuridis normatif yaitu dengan melakukan pengkajian terhadap data sekunder seperti perundang-undangan, putusan, serta bahan pustaka yang berkaitan dengan penelitian ini. Hasil penelitian menunjukkan bahwa proses penyelesaian sengketa perdata melalui BANI terdiri dari 3 (tiga) tahapan yaitu pra persidangan, masa persidangan dan pasca persidangan. Dalam implementasinya putusan BANI memiliki kekuatan eksekutorial apabila putusan arbitrase tersebut telah didaftarkan kepada kepaniteraan Pengadilan Negeri. Meskipun BANI merupakan lembaga arbitrase institusional namun dalam prinsipnya penetapan perintah pelaksanaan eksekusi tetap dilakukan oleh Pengadilan Negeri karena BANI bukanlah badan peradilan sehingga tidak memiliki perangkat jurusita, serta tidak memiliki kewenangan untuk melakukan eksekusi. Sebaiknya putusan BANI bisa dilaksanakan oleh para pihak dengan itikad baik baik dan secara sukarela tanpa harus melibatkan Pengadilan Negeri untuk melakukan eksekusi.
\end{abstract}

Kata kunci: Eksekusi, Putusan, BANI.

\begin{abstract}
Arbitration is a form of civil dispute resolution that arises from the implementation of an agreement between the parties. Pardata disputes can be resolved through the Indonesian National Arbitration Board (BANI) if the agreement closed by the parties contains an optional clause in the event of a dispute it will be resolved through BANI. The BANI decision must be carried out in good faith by the parties bound by the agreement, and if the decision is not implemented voluntarily, it will be executed by the
\end{abstract}


District Court. In this study, the authors used a normative juridical research method, namely by conducting an assessment of secondary data such as legislation, decisions, and library materials related to this research. The results showed that the civil dispute resolution process through BANI consisted of 3 (three) stages, namely the pre-trial, trial and post-trial periods. In its implementation, the BANI decision has executive power if the arbitral award has been registered with the clerk of the District Court. Even though $B A N I$ is an institutional arbitration institution, in principle the order to carry out the execution is still carried out by the District Court because BANI is not a judicial body so it does not have bailiffs and does not have the authority to carry out the execution. It is recommended that the BANI decision be implemented by the parties in good faith and voluntarily without having to involve the District Court to carry out the execution.

\section{Keywords: Execution, Verdict, BANI.}

\section{A. PENDAHULUAN}

Sengketa perdata merupakan permasalahan hukum yang sering terjadi dalam dunia bisnis sebagai akibat dari pelaksanaan suatu perjanjian. Dalam pelaksanaan perjanjian yang dibuat para pihak sering kali menimbulkan penafsiran yang berbedabeda sehingga timbul sengketa perdata. Sengketa perdata tersebut timbul akibat adanya perbedaan kepentingan, perbedaan tujuan, perselisihan, pertengkaran maupun kesalahpahaman yang mengakibatkan terhambatnya pekerjaan serta merugikan para pihak yang terikat dalam perjanjian, oleh karena itu diperlukan penyelesaian terhadap timbulnya sengketa tersebut.

Setiap pelaku bisnis tentunya menghindari adanya sengketa, namun setiap bisnis terkadang tidak bisa lepas dari suatu resiko hukum yang namanya sengketa. Dengan adanya sengketa, paling tidak setiap pelaku bisnis bisa belajar tentang mendewasakan manusia, menguatkan hubungan dan meninggikan moral, lebih mengetahui dan dapat lebih belajar untuk menanggulangi masalah, mempertinggi perkembangan pribadi, mendorong perkembangan psikologis serta meningkatkan kesadaran diri dan orang lain. 
Hukum memegang peranan yang sangat penting dalam penyelesaian sengketa akibat adanya benturan kepentingan antara para pihak yang berujung sengketa. Dalam hubungan bisnis yang melibatkan kerjasama dengan pihak lain, maka untuk mengikat para pihak dapat melaksanakan hak dan kewajibannya secara baik harus dibuat perjanjian lebih dulu. Dan untuk mengantisipasi jika terjadi sengketa atas pelaksanaan perjanjian harus pula diatur klausula penyelesaiannya dengan memilih upaya yang akan ditempuh sesuai kesepakatan bersama yakni melalui luar pengadilan atau persidangan di pengadilan. ${ }^{1}$

Sengketa perdata yang merupakan bagian dari konflik sosial kemasyarakatan dapat diselesaian melalui pengembangan sarana penyelesaian konflik sebagai salah satu perspektif fungsi hukum dalam masyarakat. ${ }^{2}$ Dalam proses penyelesaian sengketa perlu dilakukan beragam cara oleh mayarakat, salah satunya adalah dicapainya kata sepakat diantara pihak yang tersangkut sengketa. Dalam beragam cara penyelesaian sengketa yang dilakukan oleh masyarakat dalam hal ini kalangan bisnis, masing-masing memiliki kelemahan dan keuntugan jika dilihat dari bentuk penyelesaian sengketanya. ${ }^{3}$ Penyelesaian sengketa yang timbul dapat diselesaikan dengan pengolahan akal pikiran dan kesadaran masing-masing pihak yang bersengketa dengan berbagai macam cara. Berbagai macam cara penyelesaian tersebut diantaranya melalui musyawarah yang dikenal dengan penyelesaian diluar pengadilan (non litigasi) atau penyelesaian

\footnotetext{
1 Meria Utama, Hukum Ekonomi Internasional, Jakarta: PT. Fikahati Aneska, 2012, Hlm. 54.

2 Rachmadi Usman, Pilihan Penyelesaian Sengketa di Luar Pengadilan, Bandung: PT. Citra Aditya Bakti, 2013, Hlm. 1.

${ }^{3}$ Agnes M.Toar, dkk, Arbitrase di Indonesia, Jakarta: Ghalia Indonesia,1995, Hlm.1.
} 
sengketa melalui proses persidangan di pengadilan atau lebih dikenal dengan proses litigasi.

Bagi sebagian besar masyarakat lebih mengenal melakukan upaya penyelesaian sengketa yang timbul di dalam masyarakat melalui proses persidangan di pengadilan dibandingkan menyelesaikan sengketa melalui arbitrase sebagai alternatif bentuk penyelesaian sengketa di luar pengadilan. Pengetahuan masyarakat mengenai arbitrase sebagai salah satu bentuk alternatif penyelesaian sengketa ini dapat dilihat bahwa jumlah sengketa perdata yang diajukan oleh para pihak ke pengadilan jauh lebih banyak bila dibandingkan dengan penyelesaian sengketa yang diselesaikan melalui arbitrase.

Berlakunya Undang-Undang Nomor 30 Tahun 1999 tentang Arbitrase dan Alternatif Penyelesaian Sengketa (APS), merupakan wadah dan acuan hukum bagi masyarakat dalam hal ini pelaku bisnis untuk mencari solusi hukum diluar pengadilan ketika menghadapi sengketa. Dalam peraturan tersebut terdapat beberapa pilihan yang dapat ditempuh untuk menyelesaiakan sengketa yang dihadapinya, salah satunya adalah melalui arbitrase.

Untuk menyelesaikan sengketa melalui arbitrase, maka sebelumnya harus dibuat perjanjian arbitrase yang dibuat secara tertulis oleh para pihak sebagai kalusula yang tercantum dalam perjanjian pokok. ${ }^{4}$ Penyelesaian sengketa perdata melaui arbitrase dapat dilakukan melalui arbitrase $a d$ hoc atau arbitrase institusional seperti BANI.

Penyelesaian sengketa melalui arbitrase memang dinilai efektif dan memiliki keunggulan- keunggulan tertentu namun di sisi lain arbitrase juga memiliki kelemahan.

\footnotetext{
4 Republik Indonesia, Undang-Undang Nomor 30 Tahun 1999 tentang Arbitrase dan Altenatif Penyelesaian Sengketa, Pasal 1 angka 1
} 
Kelemahan tersebut di antaranya yaitu kurang diminatinya penyelesaian sengketa melalui arbitrase oleh masyarakat. Sebagian besar masyarakat lebih mengenal dan lebih sering melakukan upaya penyelesaian sengketa yang timbul di dalam masyarakat melalui proses pengadilan (litigasi) dibandingkan menyelesaikan sengketa melalui arbitrase hal ini disebakan beberapa kemungkinan salah satunya yaitu pengetahuan masyarakat mengenai alternatif penyelesaian sengketa ini beserta lembaga arbitrase (arbitrase institusional) dinilai kurang dan pemahaman terkait proses, persyaratan dan tata cara penyelesaian sengketa perdata melalui arbitrase masih sangat rendah. Oleh karena itu perlu adanya pemahaman bagi masyarakat terkait proses penyelesaian sengketa perdata melalui arbitrase agar dapat menyelesaikan sengketa yang terjadi melalui arbitrase dalam hal ini melalui lembaga arbitrase (arbitrase institusional) yaitu BANI sesuai dengan prosedur beracara yang berlaku.

Selain itu kelemahan dari proses penyelesaian sengketa melalui arbitrase ialah ketika pelaksanaan dan eksekusi putusan arbitrase. Pada dasarnya di dalam UU No.30/1999 telah dinyatakan secara jelas bahwa putusan arbitrase bersifat final dan mengikat bagi para pihak seharusnya jika putusan telah bersifat final dan mengikat, maka bagi para pihak yang bersengketa harus secara sukarela menjalankan putusan tersebut.

Diajukannya gugatan terkait putusan arbitrase oleh salah satu pihak ke Pengadilan Negeri, dapat dikatakan merupakan suatu bentuk kelemahan dalam pelaksanaan putusan arbitrase yang seakan-akan menggambarkan kurang patuhnya para pihak dalam pelaksanaan penanganan sengketa yang melibatkan pihak arbiter yang 
kemudian hasil akhiurnya dituangkan dalam putusan arbitrase. Hal ini tentunya akan menjadi pekerjaan BANI sebagai lembaga arbitrase supaya putusan arbitrase bisa dijalankan secara sukerela oleh para pihak yang bersengketa. Jika putusan aritrase tidak bisa dilaksanakan secara sukarela oleh para piha yang bersengketa, tentunya BANI sebagai lembaga arbitrase menggantungkan pelaksanaan putusan-putusannya pada lembaga yudikatif yakni Pengadilan Negeri, karena BANI tidak memiliki lembaga eksekutorial sendiri. Jadi dapat dikatakan bahwa pada dasarnya arbitrase tetap melibatkan Pengadilan Negeri sebagai badan yang dapat menerbitkan perintah eksekusi untuk melaksanakan putusan arbitrase apabila salah satu pihak tidak berkenan untuk menjalankan kewajiban secara sukarela sebagaimana yang terdapat dalam putusan arbitrase.

Oleh karena arbitrase sebagai salah satu alternatif penyelesaian sengketa perdata yang dapat ditempuh oleh para pihak, maka perlu diketahui terkait proses yang mencakup tata cara, persyaratan dan prosedur beracara penyelesaian sengketa perdata melalui BANI dari pendaftaran dan pengajuan gugatan hingga pelaksanaan eksekusi putusan arbitrase apabila para pihak tidak menjalankan kewajiban seperti yang tercantum dalam putusan. Oleh karena itu penulis akan melakukan penelitian terkait implementasi eksekusi putusan BANI dalam penyelesaian sengketa perdata. Sebagaimana telah diuraikan diatas terdapat dua permasalahan yang akan dikaji oleh penulis, yaitu bagaimana peran BANI dalam penyelesaian sengketa perdata dan bagaimana implementasi eksekusi putusan putusan BANI dalam penyelesaian sengketa perdata. 


\section{B. METODE PENELITIAN}

Dalam penelitian hukum ini penulis menggunakan jenis penelitian yuridis normatif, yakni penelitian hukum yang dilakukan dengan cara menelusuri ketentuan peraturan yang berlaku dan literatur yang berhubungan dengan masalah yang hendak diteliti sebagai bahan pustaka atau data sekunder. ${ }^{5}$ Dalam menganalisis suatu masalah hukum dilakukan dengan cara meneliti bahan pustaka, peraturan-peraturan yang tertulis atau bahan hukum yang lain sebagai bahan dasar untuk diteliti yaitu tentang tata cara, prosedur dan pelaksanaan arbitrase dalam penyelesaian sengketa perdata melalui BANI dan implementasi putusannya agar dapat ditarik kesimpulan terkait implementasi eksekusi putusan BANI dalam penyelesaian sengketa perdata.

Pengolahan data dapat dilakukan secara kualitatif dan kuantitatif. ${ }^{6}$ Pengolahan data secara kualitatif, yaitu teknik analisis data dengan cara mengorganisasikan data yang digunakan mencakup pengumpulan data, reduksi data, analisis serta interpretasi data yang kemudian disampaikan melalui deskriptif analitis untuk melakukan pemecahan suatu penelitian.

\section{PEMBAHASAN}

\section{Peran BANI dalam Penyelesaian Sengketa Perdata}

Peran BANI Penyelesaian sengketa perdata sangat penting dan bermanfaat sekali dalam mencari keadilan dan kepastian hukum. Dalam dunia usaha pilihan BANI sebagai media penyelesaian sengketa sangat diminati, karena sifatnya yang tertutup, cepat dan

\footnotetext{
${ }^{5}$ Soerjono Soekanto dan Sri Mamudji, Penelitian Hukum Normatif (Suatu Tinjauan Singkat), Jakarta, Rajawali Pers ,2001, Hlm.13-14.

${ }^{6}$ Soerjono Soekanto, Pengantar Penelitian Hukum, Cetakan III, Jakarta: UI-Press, 2015, Hlm. 68.
} 
biaya murah. Proses, cara atau tindakan untuk menyelesaikan atau memecahkan sengketa yang dapat disebakan karena adanya perbedaan pendapat, perbedaan kepentingan, perbedaan tujuan, kesalahpahaman antara dua pihak atau lebih yang berkenaan dengan orang biasa atau sipil yang berkaitan dengan kepentingan pribadi dan tidak melibatkan kepentingan publik.

Pada dasarnya para pihak yang telah sepakat memilih lembaga arbitrase dalam penyelesaian sengketa perdata yang timbul, sebelumnya harus ditungakan lebih dahulu dalam perjanjian baik itu dalam akta kompromis maupun pactum de compromittendo. Para pihak bebas untuk menentukan acara atau prosedur arbitrase yang digunakan untuk memeriksa dan menyelesaikan sengketa perdata yang timbul sepanjang tidak bertentangan dengan ketentuan atau hal-hal yang diatur dalam UU No. 30 Tahun 1999 Tentang Arbitrase dan APS. Dalam perjanjian tertulis dapat disepakati jika terjadi sengketa, sehubungan dengan pelaksanaan perjanjian tersebut dapat diselesaikan melalui arbitrase pada BANI atau memilih tunduk pada aturan BANI sebagai acara arbitrase yang digunakan untuk memeriksa sengketa. Kesepatan penyelesaian sengketa melalui BANI tersebut harus dituangkan dalam klausula perjanjian, sehingga jika memang nantinya terjadi sengketa akibat adanya hubungan hukum dalam perjanjian tersebut dapat diselesaikan melalui arbitrase di bawah penyelenggaraan BANI dengan berpedoman pada aturan BANI.

BANI didirikan berdasarkan Surat Keputusan KADIN Indonesia Nomor: SKEP/152/DPH/1977, tanggal 30 November $1977 .{ }^{7}$ BANI sebagai lembaga arbitrase

\footnotetext{
${ }^{7}$ Peraturan dan Prosedur BANI, Pasal 3 huruf a.
} 
institusional di Indonesia memiliki peraturan dan prosedur arbitrase tersendiri yang menyangkut proses penyelesaian atau prosedur beracara yang termuat dalam "Peraturan dan Prosedur Arbitrase BANI" yang berlaku sejak tanggal 1 Januari 2018. Peraturan dan Prosedur Arbitrase ini berlaku terhadap penyelesaian sengketa perdata melalui arbitrase yang diselenggarakan oleh BANI.

Dalam hal para pihak dalam suatu perjanjian arbitrase secara tegas dan jelas menentukan pilihan acara dan proses pemeriksaan sengketa perdata melalui arbitrase pada arbitrase institusional dalam hal ini BANI maka sengketa perdata tersebut akan diselesaikan oleh BANI dengan berpedoman aturan yang ditentukan oleh BANI dan berpijak pada ketentuan yang disepakati dalam perjanjian sesuai dengan UndangUndang, kebijakan BANI dan ketertiban umum.

Secara sistematis peran BANI dalam proses penyelesaian sengketa perdata melalui arbitrase pada BANI, terdiri tiga tahapan yaitu :

\section{PRA PERSIDANGAN}

Pra Persidangan adalah tahapan yang bersifat teknis administratif yang harus dipenuhi oleh para pihak sebelum persidangan atau pemeriksaan sengketa dimulai. Proses pra persidangan arbitrase terdiri dari :

1) Pendaftaran dan Penyampaian Permohonan Arbitrase

2) Pembayaran Biaya Pendaftaran

3) Pendaftaran Permohonan dalam Register BANI

4) Penunjukkan Arbiter

5) Penunjukkan Sekertaris (Panitia) oleh Ketua BANI

6) Tanggapan Termohon

7) Tuntutan Balik

8) Jawaban Tuntutan Balik 


\section{MASA PERSIDANGAN}

Tahap persidangan arbitrase adalah rangkaian proses penyelenggaraan sidangsidang dalam rangka memeriksa sengketa oleh majelis arbitrase atau arbiter tunggal sesuai dengan Peraturan dan Prosedur Arbitrase BANI dan UU No. 30 Tahun 1999 tentang Arbitrase dan APS. Sifat pemeriksaan dalam sidang arbitrase pada Badan Arbitrase Nasional Indonesia (BANI) berlangsung secara tertutup untuk umum hal ini bertujuan untuk melindungi kerahasiaan (privasi) antara para pihak yang bersengketa. Secara prosedural dan rinci tahapan persidangan arbitrase dapat dijelaskan sebagai berikut :
1) Pemanggilan Para Pihak
2) Upaya Mencari Penyelesaian Damai
3) Mendengar Para Pihak
4) Perubahan-Perubahan dan Pengajuan Selanjutnya
5) Mendengar Keterangan Saksi/Saksi Ahli
6) Penyampaian Kesimpulan oleh Para Pihak
7) Penutupan Persidangan
8) Putusan Akhir
9) Pertimbangan Putusan
10) Penandatanganan Putusan
11) Penyampaian Putusan

\section{PASCA PERSIDANGAN}

Merupakan suatu tahapan yang memberikan kesempatan kepada para pihak memperbaiki kekeliruan aministrasi dalam putusan arbitrase, pendaftaran putusan ke Pengadilan Negeri dan pelaksanaan putusan arbitrase.

1) Pembetulan terhadap Kesalahan- Kesalahan

2) Pendaftaran Putusan

3) Pelaksanaan Putusan 
Ketiga tahapan tersebut merupakan satu kesatuan yang memiliki keterkaitan yang merupakan suatu rangkaian proses penyelesaian sengketa perdata melalui arbitrase pada BANI.

\section{Implementasi Eksekusi Putusan BANI}

Implementasi merupakan suatu bentuk pelaksanaan atau penerapan suatu hal dalam praktik. Kemudian yang dimaksud dengan kekuatan eksekutorial adalah kekuatan untuk pelaksanaan mengenai apa yang telah ditetapkan dalam suatu putusan dengan cara memaksa yang dijembatani oleh alat negara. ${ }^{8}$

Putusan BANI adalah hasil akhir dari rangkaian pemeriksaan terhadap alasan dan bukti para pihak oleh majelis arbitrase atau arbiter tunggal BANI. ${ }^{9}$ Putusan BANI bersifat final, mengikat para pihak (binding) dan mempunyai kekuatan hukum tetap. Sifat tersebut menunjukkan bahwa terhadap putusan yang dijatuhkan oleh BANI tidak terbuka bagi para pihak untuk melakukan upaya hukum baik itu perlawanan, banding, kasasi, maupun permohonan peninjauan kembali. Putusan langsung bersifat final serta memiliki kekuatan hukum tetap sejak putusan arbitrase tersebut diputuskan oleh majelis arbitrase atau arbitrase tunggal.

Pada prinsipnya suatu putusan arbitrase yang diputus oleh majelis arbitrase atau arbiter tunggal ialah bertujuan untuk menangani persoalan atau sengketa yang terjadi serta menetapkan hak atau hukumnya, dan mengharuskan para pihak sera sukarela dengan penuh itikad baik tunduk menjalankan putusan tersebut. Namun dalam

\footnotetext{
${ }^{8}$ Soedikno Mertokusumo sebagaimana dikutip oleh Novreddy Sihombing, Kekuatan Hukum Putusan Badan Penyelesaian Sengketa Konsumen, JOM Fakultas Hukum, Volume 2 No. 1 Februari 2015, Hlm. 4. ${ }^{9}$ Peraturan dan Prosedur Arbitrase BANI, Pasal 3 huruf m.
} 
praktiknya setelah putusan arbitrase dijatuhkan terkadang salah satu pihak yang kalah atau merasa tidak puas dengan putusan arbitrase, pihak tersebut tidak melaksanakan apa yang telah diputuskan atau kewajibannya secara sukarela. Oleh karena itu dalam putusan arbitrase sangat penting untuk ditentukan jangka waktu pelaksanaan putusan.

Penentuan jangka waktu pelaksanaan putusan ini diatur dalam Pasal 33 Peraturan dan Prosedur Arbitrase BANI, yakni adanya penetapan sanksi dan/atau denda dan/atau tingkat bunga dalam jumlah yang wajar apabila pihak yang kalah lalai dalam melaksanakan putusan itu yang ditetapkan oleh majelis arbitrase atau arbiter tunggal jika dalam batas waktu yang ditetapkan, pihak yang kalah tidak melaksanakan putusan. ${ }^{10}$

Kekuatan eksekutorial perlu dilakukan oleh BANI, jika setelah melewati batas waktu pelaksanaan putusan, salah satu pihak tidak bersedia melaksanakan putusan arbitrase secara sukarela. Kekuatan eksekutorial merupakan kekuatan untuk memaksa pihak yang tidak patuh melaksanakan apa yang ditetapkan dalam putusan melalui perintah Ketua Pengadilan Negeri atas dasar permohonan salah satu pihak.

Pelaksanaan eksekusi secara paksa oleh Ketua Pengadilan Negeri sebaiknya menjadi upaya terakhir yang ditempuh para pihak, hal ini selaras dengan prinsip penyelesaian sengketa melalui arbitrase yang mengedepankan konsensualisme, otonomi para pihak, sederhana dan itikad baik.

Pada prinsipnya agar suatu putusan arbitrase dapat dilaksanakan maka putusan arbitrase wajib untuk didaftarkan terlebih dahulu kepada panitera Pengadilan Negeri

${ }^{10}$ Peraturan dan Prosedur Arbitrase BANI, Pasal 33 
oleh arbiter yang mengadili sengketa atau kuasanya kepada panitera pengadilan negeri dalam waktu paling lama 30 (tiga puluh) hari terhitung sejak tanggal putusan diucapkan, hal ini merujuk pada Pasal 59 ayat 1 UU No. 30 Tahun 1999 tentang Arbitrase dan APS. Kemudian dalam Pasal 34 Peraturan dan Prosedur Arbitrase BANI juga mensyaratkan bahwa pihak yang menang dapat mendaftarkan putusan dan meminta pelaksanaan eksekusi putusan kepada Ketua Pengadilan Negeri tanpa terbatasi dengan kerahasiaan proses arbitrase. $^{11}$

Hal ini berarti meskipun dalam pemeriksaan sengketa melalui Arbitrase pada BANI sangat menjunjung prinsip kerahasiaan, karena dalam praktik persidangan di BANI sifatnya tertutup, namun bukan berarti putusan BANI tersebut tidak didaftarkan kepada Pengadilan Negeri ataupun tidak diajukannya permohonan pelaksanaan eksekusi putusan tersebut oleh salah satu pihak. Karena pendaftaran putusan BANI menentukan dapat atau tidaknya putusan arbitrase dilaksanakan secara paksa oleh alat-alat negara.

Permohonan eksekusi baru mempunyai nilai yang sah apabila putusan arbitrase telah didaftarkan terlebih dahulu ke Pengadilan Negeri. Tujuan pendaftaran putusan BANI ialah agar putusan BANI tersebut dapat dimintakan eksekusi oleh salah satu pihak apabila pihak yang lainnya tidak berkenan untuk melaksanakan putusan BANI tersebut secara sukarela. ${ }^{12}$

Pihak yang hendak meminta eksekusi terhadap putusan BANI kepada ketua Pengadilan Negeri harus mengajukan surat permohonan eksekusi terlebih dahulu.

\footnotetext{
${ }^{11}$ Peraturan dan Prosedur Arbitrase BANI, Pasal 34.

12 Susanti Adi Nugroho, Penyelesaian Sengketa Arbitrase dan Penerapan Hukumnya, Jakarta: Kencana, 2015, Hlm. 275.
} 
Sebelum Ketua Pengadilan Negeri mengeluarkan penetapan perintah eksekusi perlu terlebih dahulu pemberian exequatur terhadap putusan. Pada dasarnya tujuan permintaan exequatur ialah untuk memberikan kesempatan kepada Ketua Pengadilan Negeri untuk memeriksa dan meneliti serta menentukan dapat atau tidaknya putusan arbitrase tersebut dieksekusi. ${ }^{13}$ Apabila Ketua Pengadilan Negeri telah memberi exequatur terhadap putusan arbitrase, maka terhadap putusan tersebut dapat langsung dikeluarkan penetapan perintah eksekusi. ${ }^{14}$ Ketua Pengadilan Negeri tidak diberikan kewenangan untuk melakukan pemeriksaan terhadap materi putusan arbitrase. ${ }^{15}$ Tujuan tidak diperiksanya mataeri yang terdapat dalam putusan arbitrase oleh Ketua Pengadilan Negeri ialah agar putusan arbitrase bersifat mandiri, final dan mengikat. ${ }^{16}$ Putusan arbitrase dapat dilaksanakan sesuai ketentuan pelaksanaan putusan dalam perkara perdata dan telah mempunyai kekuatan hukum tetap setelah dibubuhi perintah Ketua Pengadilan Negeri. ${ }^{17}$

Implementasinya, bahwa putusan BANI baru memiliki kekuatan eksekutorial apabila putusan tersebut telah didaftarkan oleh majelis arbitrase atau arbiter tunggal yang memeriksa dan memutus sengketa kepada kepaniteraan Pengadilan Negeri yang berwenang, dalam jangka waktu yang telah ditentukan dalam UU No. 30 Tahun 1999 tentang Arbitrase dan APS. Jadi dalam hal ini apabila suatu putusan BANI tidak didaftarkan dalam jangka waktu yang telah ditetapkan maka apabila salah satu pihak

\footnotetext{
${ }^{13}$ Ibid., Hlm. 278.

${ }^{14}$ Ibid.,

15 Republik Indonesia, Undang-Undang No. 30 Tahun 1999 Tentang Arbitrase dan Alternatif Penyelesaian Sengketa, Pasal 62 ayat 4.

${ }^{16}$ Ibid.,

17 Republik Indonesia, Undang-Undang No. 30 Tahun 1999 Tentang Arbitrase dan Alternatif Penyelesaian Sengketa, Pasal 64.
} 
tidak melaksanakan putusan BANI secara sukarela putusan arbitrase tersebut tidak dapat dilaksanakan dan tidak dapat dimohonkan untuk eksekusi.

Pendaftaran putusan arbitrase pada Pengadilan Negeri bersifat imperatif, artinya jika tidak dilakukan pendaftaran putusan maka permohonan eksekusi tidak dapat diterima. ${ }^{18}$ Pendaftaran putusan arbitrase bersifat konstitutif yakni satu rangkaian dalam proses arbitrase, dan jika tidak didaftarkan sebelumnya maka putusan arbitrase tersebut tidak dapat dieksekusi. Artinya pendaftaran putusan arbitrase bukan hanya bersifat administratif belaka ${ }^{19}$

Dalam hal ini yang berwenang untuk memberikan perintah eksekusi dan pelaksanaan eksekusi hanyalah Pengadilan Negeri karena merupakan suatu badan peradilan resmi pemerintah sehingga dalam hal ini meskipun BANI merupakan suatu lembaga arbitrase institusional namun dalam prinsipnya yang berwenang untuk menetapkan perintah pelaksanaan eksekusi ialah Pengadilan Negeri karena BANI bukan merupakan badan peradilan resmi pemerintah tetapi hanya lembaga swasta yang tidak memiliki perangkat jurusita, karena perangkat jurusita hanya terdapat di lingkungan peradilan umum serta BANI juga tidak memiliki lembaga eksekutorial tersendiri karena bukan termasuk ke dalam badan peradilan.

Sehingga dalam hal ini kekuatan eksekutorial dari putusan BANI bergantung apakah putusan BANI tersebut telah didaftarkan oleh arbiter yang memeriksa dan memutus sengketa atau belum karena apabila putusan BANI tersebut belum didaftarkan

\footnotetext{
${ }^{18}$ Ibid., Hlm. 275.

${ }^{19}$ Munir Fuady, Arbitrase Nasional Alternatif Penyelesaian Sengketa Bisnis, Jakarta: PT.Citra Aditya Bakti, 2000, Hlm. 162.
} 
di Kepaniteraan Pengadilan Negeri maka putusan BANI tersebut tidak dapat dilaksanakan dan tidak dapat dimohonkan untuk dieksekusi atau dengan kata lain tidak memiliki kekuatan eksekutorial. Sehingga dapat dikatakan bahwa kekuatan eksekutorial dari putusan BANI barulah timbul ketika putusan BANI tersebut telah didaftarkan oleh arbiter atau majelis arbitrase yang memeriksa dan memutus sengketa kepada Kepaniteraan Pengadilan Negeri.

Dalam hal ini berarti peyelesaian sengketa melalui arbitase tetap membutuhkan pengadilan dalam pelaksanaan eksekusi putusan BANI sehingga dapat dikatakan bahwa pengadilan tetap memiliki peranan yang sangat penting terhadap penyelesaian sengketa yang diselesaikan melalui arbitrase terkait dengan pelaksanaan putusan arbitrase yang tidak dilaksanaksan secara sukarela oleh para pihak.

Peranan pengadilan dalam pelaksanaan eksekusi putusan arbitrase dapat dirumuskan sebagai berikut $: 20$

1) Pemberian Exequatur

2) Penetapan Perintah Eksekusi

3) Melakukan Teguran atau Annmaning

4) Pelaksanaan Eksekusi Putusan Baik Melalui Sita, Lelang Maupun Pengosongan

\section{PENUTUP}

Peran BANI sangat besar sekali dalam memberikan kepastian hukum dan keadilan pada proses persidangan perdata, ada media lain diluar Pengadilan Negeri yang

\footnotetext{
20 Joejoen Tjahjani, Peranan Pengadilan Dalam Pelaksanaan Putusan Arbitrase, Jurnal Independent, Volume 2 No. 1, Hlm. 36-37.
} 
bisa dipakai dalam penyelesaian sengketa perdata. Proses penyelesaian sengketa perdata melalui BANI harus didasarkan pada klausul atau perjanjian arbitrase yang termuat dalam perjanjian tertulis yang disepakati oleh para pihak. Secara sistematis proses penyelesaian sengketa perdata melalui arbitrase pada BANI, dapat dibagi menjadi tiga tahapan yaitu pra persidangan, masa persidangan dan pasca persidangan. Ketiga tahapan tersebut merupakan satu kesatuan yang memiliki keterkaitan yang merupakan suatu rangkaian proses penyelesaian sengketa perdata melalui BANI. Dalam implementasinya putusan BANI baru memiliki kekuatan eksekutorial apabila putusan tersebut telah didaftarkan oleh majelis arbitrase atau arbiter tunggal yang memeriksa dan memutus sengketa kepada kepaniteraan Pengadilan Negeri dalam jangka waktu yang telah ditentukan dalam UU No. 30 Tahun 1999 tentang Arbitrase dan APS. Hal mana yang berwenang untuk menetapkan perintah pelaksanaan eksekusi ialah Pengadilan Negeri karena BANI bukan merupakan badan peradilan resmi pemerintah yang tidak memiliki perangkat jurusita. Ketua Pengadilan Negeri hanya berwenang untuk memeriksa pokok perkara dan tidak diperkenanakan untuk memeriksa materi putusan arbitrase. Dalam hal ini berarti penyelesaian sengketa melalui arbitase tetap membutuhkan pengadilan dalam pelaksanaan eksekusi putusan BANI sehingga dapat dikatakan bahwa pengadilan memiliki peranan yang sangat penting terhadap penyelesaian sengketa yang diselesaikan melalui arbitrase terkait dengan pelaksanaan putusan arbitrase yang tidak dilaksanakan secara sukarela oleh para pihak. 


\section{DAFTAR PUSTAKA}

\section{Perundang-undangan:}

Republik Indonesia, Undang-undang Nomor 30 Tahun 1999 tentang Arbitrase dan Alternatif Penyelesaian Sengketa, Lembaran Negara Republik Indonesia Tahun 1999 Nomor 138.

Badan Arbitrase Nasional Indonesia, Peraturan dan Prosedur Arbitrase BANI 2018

\section{Buku:}

Fuady, Munir, Arbitrase Nasional Alternatif Penyelesaian Sengketa Bisnis, Jakarta: PT.Citra Aditya Bakti, 2000.

M.Toar, Agnes dkk., Arbitrase di Indonesia, Jakarta: Ghalia Indonesia, 1995.

Nugroho, Susanti Adi, Penyelesaian Sengketa Arbitrase dan Penerapan Hukumnya, Jakarta: Kencana, 2015.

Soekanto, Soerjono, Pengantar Penelitian Hukum, Cetakan III, Jakarta: UI-Press, 2015.

Usman, Rachmadi, Pilihan Penyelesaian Sengketa di Luar Pengadilan, Bandung: PT. Citra Aditya Bakti, 2013

Utama, Meria, Hukum Ekonomi Internasional, Jakarta: PT. Fikahati Aneska, 2012.

\section{Jurnal Ilmiah:}

Joejoen Tjahjani, Peranan Pengadilan Dalam Pelaksanaan Putusan Arbitrase, Jurnal Independent, Volume 2 No. 1.

Novreddy Sihombing, Kekuatan Hukum Putusan Badan Penyelesaian Sengketa Konsumen, JOM Fakultas Hukum, Volume 2 No. 1 Februari 2015 